\title{
Prevalence of ESBL-producing Enterobacteriaceae in raw vegetables
}

\author{
E. A. Reuland • N. al Naiemi • S. A. Raadsen • \\ P. H. M. Savelkoul • J. A. J. W. Kluytmans • \\ C. M. J. E. Vandenbroucke-Grauls
}

Received: 16 February 2014 / Accepted: 24 April 2014 /Published online: 22 May 2014

(C) The Author(s) 2014. This article is published with open access at Springerlink.com

\begin{abstract}
To determine whether extended-spectrum betalactamase (ESBL)-producing Enterobacteriaceae (ESBLE) are present in retail raw vegetables in Amsterdam, the Netherlands, we collected 119 samples of 15 different types of vegetables from various sources. After culture, strain identification and susceptibility testing, ESBL-encoding genes were characterised by a microarray. Four of the 15 vegetable types were contaminated with ESBL-E. Seven samples (6 \%) yielded ESBL-E.

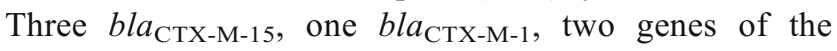
CTX-M-9 group and one SHV ESBL-encoding gene were found. The ESBL genes were similar to what is found in enterobacterial strains from human origin. Therefore, raw vegetables might be a source of resistance genes for the enterobacterial strains found in humans.
\end{abstract}

E. A. Reuland $(\bowtie) \cdot$ N. al Naiemi $\cdot$ S. A. Raadsen $\cdot$

P. H. M. Savelkoul · J. A. J. W. Kluytmans •

C. M. J. E. Vandenbroucke-Grauls

Department of Medical Microbiology and Infection Control, VU

University Medical Center, P.O. Box 7057, 1007 MB Amsterdam,

The Netherlands

e-mail: e.reuland@vumc.nl

N. al Naiemi

Laboratory for Medical Microbiology and Public Health, Enschede,

The Netherlands

N. al Naiemi

Medical Microbiology and Infection Control, Ziekenhuisgroep

Twente, Almelo, The Netherlands

J. A. J. W. Kluytmans

Department of Medical Microbiology and Infection Control, Amphia

Hospital, Breda, The Netherlands

\section{Introduction}

Extended-spectrum beta-lactamases (ESBLs) are emerging rapidly worldwide. ESBLs have been detected in patients without prior healthcare contact, even in countries with low consumption of antibiotics (ESAC-Net; http://www.ecdc. europa.eu/en/activities/surveillance/esac-net/pages/index. aspx). Major sources of ESBLs in the community can be envisaged: resistant strains from high ESBL prevalence reservoirs (hospitals and long-term care facilities) or resistant strains present in the food chain, environment or water sources [1]. The complex dynamics and dissemination of antibiotic resistance and its relation to different reservoirs has been depicted by Davies and Davies [2] and by Wellington et al. [3]. Especially, the food chain has recently attracted attention because a high prevalence of resistance genes in foodproducing animals like poultry was reported; this is related to the high rate of antimicrobial drug use in the livestock sector $[4,5]$. In addition, resistance genes are also widespread in agriculture $[2,6]$. Ruimy et al. observed that vegetables in France were often contaminated with resistance genes [7]. In 2011, a Shiga toxin-producing Escherichia coli (STEC) outbreak in Germany, caused by ESBL-producing E. coli, was traced to sprouts [8].

The aim of this study was to evaluate the presence of ESBL-producing Enterobacteriaceae (ESBL-E) in raw vegetables in the region of Amsterdam, the Netherlands.

\section{Materials and methods}

Study design

In October, 2010, and March, 2011, 119 samples from 15 different types of retail vegetables were purchased from an organic store, the market, a store of a large 
Table 1 Overview of vegetable types in relation to extendedspectrum beta-lactamase (ESBL)encoding genes and plasmids

\begin{tabular}{lllll}
\hline Store & Vegetable & Species & ESBL gene & Plasmids \\
\hline Organic store & Bean sprouts & Klebsiella pneumoniae & bla $_{\text {SHV-12 }}$ & ColEtp, T \\
& Bean sprouts & Klebsiella pneumoniae & bla $a_{\text {CTX-M-14 }}$ & ColE, FIA \\
& Radish & Enterobacter cloacae & bla $a_{\text {CTX-M-15 }}$ & ColEtp, HI2 \\
& Spring onion & Enterobacter amnigenus & bla $a_{\text {CTX-M-15 }}$ & HI2 \\
& Parsnip & Citrobacter braakii & bla $a_{\text {CTX-M-1 }}$ & HI1 \\
Market & Bean sprouts & Klebsiella pneumoniae & bla $a_{\text {CTX-M-14 }}$ & ColEtp, FIA, T \\
Supermarket (local) & Bean sprouts & Enterobacter cloacae & bla $_{\text {CTX-M-15 }}$ & ColEtp, HI2 \\
\hline
\end{tabular}

Dutch supermarket chain and a local supermarket. We obtained two samples from each vegetable type and from each different source. We focused on vegetables grown on and in the ground/soil, and on (mung) bean sprouts. The 15 vegetables included: beet root, Brussels sprouts, carrots, cauliflower, celery, chicory, cucumber, lettuce, mushrooms, parsnip, potatoes, radish, spinach, spring onion and (mung) bean sprouts. Of each unwashed sample, $1 \mathrm{~g}$ was ground and inoculated in $10 \mathrm{ml}$ of trypticase soy broth (Becton Dickinson, Breda, the Netherlands) supplemented with ceftazidime $0.5 \mathrm{mg} /$ $\mathrm{L}$ (incubation overnight, at $37^{\circ} \mathrm{C}$ ). Thereafter, the broth was subcultured on a selective screening agar (EbSA, Cepheid Benelux, Apeldoorn, the Netherlands) (incubation overnight, $37^{\circ} \mathrm{C}$ ) [9]. We only analysed enterobacterial species.

\section{Phenotypic and genotypic testing}

Identification and antibiotic susceptibility testing were performed with the Vitek 2 system (bioMérieux, Marcy l'Etoile, France). The minimum inhibitory concentration (MIC) breakpoints according to the Clinical and Laboratory Standards Institute (CLSI) were used [10]. Phenotypic ESBL production was confirmed with the combination disc diffusion test with clavulanic acid (Rosco, Taastrup, Denmark) [11].

After DNA isolation (QIAamp DNA mini kit, Qiagen, Venlo, the Netherlands), isolates were screened for ESBL resistance genes by a microarray, which enables the distinction between the most prevalent ESBLs, including CTX-M-1 and CTX-M-15 (Check-MDR CT103, Check-Points, Wageningen, the Netherlands) [12]. The presence of carbapenemase genes and plasmid-mediated AmpCs was also tested with the microarray. Plasmids were identified by polymerase chain reaction (PCR)-based replicon typing [13]. The strains were tested with 22 primer sets for Inc groups (ColE, FIA, ColEtp, HI1, HI2, T, Inc I1, FrepB, R, FIIs, FIB, $\mathrm{P}, \mathrm{B} / \mathrm{O}, \mathrm{A} / \mathrm{C}, \mathrm{K}, \mathrm{U}, \mathrm{L} / \mathrm{M}, \mathrm{W}, \mathrm{N}, \mathrm{X}, \mathrm{FIC}, \mathrm{Y})$.

\section{Results}

Seven of the 119 samples (6\%) yielded ESBL-E (Table 1). The type of contaminated vegetables, ESBL-producing strains, genes and plasmids found are described in Table 1. The contaminated samples were from four of the 15 vegetable types $(27 \%)$. The majority of ESBL-positive samples $(5 / 7)$ were derived from an organic store, the prevalence of ESBL-E in organically grown vegetables was $15.6 \%(5 / 32)[95 \%$ confidence interval (CI): 6.4-32.2] and in conventionally grown vegetables it was $2.3 \%(2 / 87)$ (95\% CI: 0.14-8.5). The risk difference (RD) between the two types of vegetables was significant (RD 13.3\%, 95\% CI: 0.35-26.31). The variation in plasmids and genes found is in accordance with the findings of Carattoli et al. [13].

A high rate of co-resistance to gentamicin, co-trimoxazole and nitrofurantoin was observed. Two out of these seven ESBL-producing strains were multi-resistant, but all were susceptible to meropenem and imipenem [14].

\section{Discussion}

Our results document the presence of ESBL-E in retail raw vegetables obtained in Amsterdam, the Netherlands, which implies that raw vegetables may be a source of resistance genes. These results correlate with other studies pointing to vegetables as a possible route for the dissemination of resistance genes in the community [4, 7, 15, 16].

Different pathways might be relevant to explain why these resistance genes were found on raw vegetables [2, 6]. Knapp et al. showed that the levels of antibiotic resistance genes in soil have increased considerably over the past 70 years in the Netherlands [17]. Other reservoirs of antibiotic resistance genes are the aquatic system and sewage, created by antibiotic use and waste disposal [2, 4, 18, 19]. Fresh produce can also become contaminated during processing [15]. We bought the vegetables at the market or at the shop itself, thereby providing information on the vegetables actually bought by the 
consumer, but this implies that contamination could have occurred during human handling.

A remarkable finding of the present study is that organic vegetables were more often contaminated with ESBL-E than conventionally produced vegetables. Several studies examined the potential differences between organic and conventional products [18]. It has been shown that different microorganisms and contaminants are found on organic produce compared to conventionally grown vegetables due to the use of manure, no pesticides and a different processing [18].

The resistance genes present in our samples belonged mainly to the CTX-M family, and especially CTX-M-15 was found. CTX-M-15 is the most common type of ESBL in Europe and has been increasingly described in community isolates. Also, a study in Amsterdam, among Dutch outpatients with gastrointestinal complaints, showed that the most prevalent ESBL-E is CTX-M-15-producing E. coli [20]. A study performed in the region of Rotterdam describes the clinical and molecular characteristics of bacteraemia caused by ESBLs, also showing that these strains are the most prevalent [21]. Therefore, although the species containing these genes were not $E$. coli but other enterobacterial species, these may act as a reservoir for mobile drug resistance genes and transfer these genes to the non-pathogenic $E$. coli present in the gut $[22,23]$. The high rate of co-resistance that we noted may add to the acquisition of multi-drug resistance from the food chain.

Sprouts were found to be most often contaminated, but with other ESBL-producing species than E. coli. These vegetables have often been implicated in STEC outbreaks and it has been postulated that they may constitute a common gene pool for antibiotic resistance [8].

In a previous study, we found that ESBL-E carried several different plasmids, some of which we also detected in the enterobacterial strains found on vegetables in the present study [20]. The most common plasmids in humans were ColE and FrepB, but ColEtp and HI2 were also found in a substantial number of strains. Hence, plasmid transfer among Enterobacteriaceae found on vegetables and those of the human gut seems possible. It is, of course, not possible, from the present study, to infer how frequent such transfer could be.

In conclusion, we found classic ESBL genes in raw vegetables, namely CTX-M-1 and CTX-M-15, and several plasmids that are commonly associated with these genes. The possible impact of our findings on human health highlights the need to further evaluate the presence of ESBL-E in raw vegetables and to explore whether the exchange of resistance genes between these ESBL-E and other enterobacterial species in the human gut does indeed occur.
Acknowledgements Part of the results of this study was presented at the 21st European Congress of Clinical Microbiology and Infectious Diseases (ECCMID), Milan, Italy, May 2011, oral presentation O102.

Funding This work was supported by ZonMw, the Netherlands Organisation for Health Research and Development (grant number 125020011).

Conflict of interest The authors declare that they have no conflict of interest.

Open Access This article is distributed under the terms of the Creative Commons Attribution License which permits any use, distribution, and reproduction in any medium, provided the original author(s) and the source are credited.

\section{References}

1. Ben-Ami R, Schwaber MJ, Navon-Venezia S, Schwartz D, Giladi M, Chmelnitsky I, Leavitt A, Carmeli Y (2006) Influx of extendedspectrum beta-lactamase-producing enterobacteriaceae into the hospital. Clin Infect Dis 42(7):925-934

2. Davies J, Davies D (2010) Origins and evolution of antibiotic resistance. Microbiol Mol Biol Rev 74(3):417-433

3. Wellington EM, Boxall AB, Cross P, Feil EJ, Gaze WH, Hawkey PM, Johnson-Rollings AS, Jones DL, Lee NM, Otten W, Thomas CM, Williams AP (2013) The role of the natural environment in the emergence of antibiotic resistance in gram-negative bacteria. Lancet Infect Dis 13(2): 155-165

4. Mesa RJ, Blanc V, Blanch AR, Cortés P, González JJ, Lavilla S, Miró E, Muniesa M, Saco M, Tórtola MT, Mirelis B, Coll P, Llagostera M, Prats G, Navarro F (2006) Extended-spectrum beta-lactamase-producing Enterobacteriaceae in different environments (humans, food, animal farms and sewage). J Antimicrob Chemother 58(1):211-215

5. Overdevest I, Willemsen I, Rijnsburger M, Eustace A, Xu L, Hawkey P, Heck M, Savelkoul P, Vandenbroucke-Grauls C, van der Zwaluw K, Huijsdens X, Kluytmans J (2011) Extended-spectrum $\beta$ lactamase genes of Escherichia coli in chicken meat and humans, The Netherlands. Emerg Infect Dis 17(7):1216-1222

6. Heuer H, Schmitt H, Smalla K (2011) Antibiotic resistance gene spread due to manure application on agricultural fields. Curr Opin Microbiol 14(3):236-243

7. Ruimy R, Brisabois A, Bernede C, Skurnik D, Barnat S, Arlet G, Momcilovic S, Elbaz S, Moury F, Vibet MA, Courvalin P, Guillemot D, Andremont A (2010) Organic and conventional fruits and vegetables contain equivalent counts of Gram-negative bacteria expressing resistance to antibacterial agents. Environ Microbiol 12(3):608615

8. Buchholz U, Bernard H, Werber D, Böhmer MM, Remschmidt C, Wilking H, Deleré Y, an der Heiden M, Adlhoch C, Dreesman J, Ehlers J, Ethelberg S, Faber M, Frank C, Fricke G, Greiner M, Höhle M, Ivarsson S, Jark U, Kirchner M, Koch J, Krause G, Luber P, Rosner B, Stark K, Kühne M (2011) German outbreak of Escherichia coli O104:H4 associated with sprouts. N Engl J Med 365(19):17631770

9. Naiemi NA, Murk JL, Savelkoul PH, Vandenbroucke-Grauls CM, Debets-Ossenkopp YJ (2009) Extended-spectrum beta-lactamases screening agar with AmpC inhibition. Eur J Clin Microbiol Infect Dis 28(8):989-990

10. Clinical and Laboratory Standards Institute (CLSI) (2008) Performance standards for antimicrobial susceptibility testing; Eighteenth informational supplement. CLSI document M100-S18. CLSI, Wayne, PA, USA 
11. al Naiemi N, Cohen Stuart J, Leverstein van Hall M (2008) NVMM guideline of the Dutch Society for Medical Microbiology for screening and confirmation of extended-spectrum beta-lactamases (ESBLs) in Enterobacteriaceae (in Dutch). http://www.nvmm.nl/richtlijnen/ esbl

12. Cuzon G, Naas T, Bogaerts P, Glupczynski Y, Nordmann P (2012) Evaluation of a DNA microarray for the rapid detection of extendedspectrum beta-lactamases (TEM, SHV and CTX-M), plasmidmediated cephalosporinases (CMY-2-like, DHA, FOX, ACC-1, ACT/MIR and CMY-1-like/MOX) and carbapenemases (KPC, OXA-48, VIM, IMP and NDM). J Antimicrob Chemother 67(8): 1865-1869

13. Carattoli A, Bertini A, Villa L, Falbo V, Hopkins KL, Threlfall EJ (2005) Identification of plasmids by PCR-based replicon typing. J Microbiol Methods 63(3):219-228

14. Magiorakos AP, Srinivasan A, Carey RB, Carmeli Y, Falagas ME, Giske CG, Harbarth S, Hindler JF, Kahlmeter G, Olsson-Liljequist B, Paterson DL, Rice LB, Stelling J, Struelens MJ, Vatopoulos A, Weber JT, Monnet DL (2012) Multidrug-resistant, extensively drug-resistant and pandrug-resistant bacteria: an international expert proposal for interim standard definitions for acquired resistance. Clin Microbiol Infect 18(3):268-281

15. Schwaiger K, Helmke K, Hölzel CS, Bauer J (2011) Antibiotic resistance in bacteria isolated from vegetables with regards to the marketing stage (farm vs. supermarket). Int J Food Microbiol 148(3): 191-196

16. Hassan SA, Altalhi AD, Gherbawy YA, El-Deeb BA (2011) Bacterial load of fresh vegetables and their resistance to the currently used antibiotics in Saudi Arabia. Foodborne Pathog Dis 8(9):1011-1018
17. Knapp CW, Dolfing J, Ehlert PA, Graham DW (2010) Evidence of increasing antibiotic resistance gene abundances in archived soils since 1940. Environ Sci Technol 44(2):580-587

18. Hoogenboom LA, Bokhorst JG, Northolt MD, van de Vijver LP, Broex NJ, Mevius DJ, Meijs JA, Van der Roest J (2008) Contaminants and microorganisms in Dutch organic food products: a comparison with conventional products. Food Addit Contam Part A Chem Anal Control Expo Risk Assess 25(10):1195-1207

19. Blaak H, Schets FM, Italiaander R, Schmitt H, de Roda Husman AM (2010) Antibiotic resistant bacteria in surface water in an area with a high density of animal farms in the Netherlands. RIVM report 703719031

20. Reuland EA, Overdevest IT, Al Naiemi N, Kalpoe JS, Rijnsburger MC, Raadsen SA, Ligtenberg-Burgman I, van der Zwaluw KW, Heck M, Savelkoul PH, Kluytmans JA, Vandenbroucke-Grauls CM (2013) High prevalence of ESBL-producing Enterobacteriaceae carriage in Dutch community patients with gastrointestinal complaints. Clin Microbiol Infect 19(6):542-549

21. van der Bij AK, Peirano G, Goessens WH, van der Vorm ER, van Westreenen M, Pitout JD (2011) Clinical and molecular characteristics of extended-spectrum-beta-lactamase-producing Escherichia coli causing bacteremia in the Rotterdam Area, Netherlands. Antimicrob Agents Chemother 55(7):3576-3578

22. Cantón R, Coque TM (2006) The CTX-M beta-lactamase pandemic. Curr Opin Microbiol 9(5):466-475

23. Raphael E, Wong LK, Riley LW (2011) Extended-spectrum betalactamase gene sequences in gram-negative saprophytes on retail organic and nonorganic spinach. Appl Environ Microbiol 77(5): $1601-1607$ 